\title{
Influence of religiosity on medical students' mental health
}

\author{
Influência da religiosidade sobre a saúde mental dos acadêmicos de medicina
}

\author{
Larissa Cruvinel Leite' 1 | $\mid$ larissacruvinelleite@gmail.com \\ Larissa Vitoria Dornelas ${ }^{1}$ (D) dornelaslarissav@gmail.com \\ Laura de Souza Bechara Secchin'1 (D) laura.bechara@suprema.edu.br
}

\begin{abstract}
Introduction: Mental health was included as one of the top ten health indicators and studies have shown it is related to religiosity and spirituality $(\mathrm{R} / \mathrm{S})$.

Objective: The aim of the present study is to evaluate whether the degree of R/S of medical students influences anxiety and depression disorders during undergraduate school.

Method: This study was carried out with a convenience non-probabilistic sample, consisting of 298 students. The Duke Religiosity Index in Brazilian Portuguese (P-DUREL) was used in questionnaire form, whereas, to map depression, anxiety and stress, DASS-21 was applied.

Results: It was demonstrated that the different dimensions of religiosity have no association with the students' emotional disorders, anxiety and stress.

Conclusions: It is possible to propose recommendations for future research, so that the results can be used in meta-analysis studies. Studies that did not show a significant association between the variables cannot be neglected, so that the positive and negative dimensions of the association between $\mathrm{R} / \mathrm{S}$ and mental health can be investigated.
\end{abstract}

Keywords: Religion; Spirituality; Depression; Anxiety; Medical Students.

\section{RESUMO}

Introdução: A saúde mental foi incluída como um dos dez principais indicadores de saúde, e estudos demonstraram sua relação com religiosidade e espiritualidade (R/E).

Objetivo: Este estudo teve como objetivo avaliar se o grau de R/E dos acadêmicos de Medicina influencia em transtornos de ansiedade e depressão no decorrer da graduação.

Método: Este trabalho foi realizado com uma amostra não probabilística, por conveniência, constituída de 298 acadêmicos. Utilizou-se, na forma de questionários, o Índice de Religiosidade de Duke em português brasileiro (P-DUREL), e, para mapeamento de depressão, ansiedade e estresse, aplicou-se a DASS-21.

Resultado: Foi demonstrado que as diferentes dimensões da religiosidade não possuem associação com os transtornos emocionais depressão, ansiedade e estresse dos estudantes.

Conclusões: É possível propor recomendações para pesquisas futuras, de modo que os resultados possam ser utilizados em estudos de metanálise. Estudos que não apresentaram relação significativa entre as variáveis não podem ser negligenciados para que sejam investigadas as dimensões positivas e negativas da associação entre R/E e saúde mental.

Palavras-chave: Religião; Espiritualidade; Depressão; Ansiedade; Estudantes de Medicina.

${ }^{1}$ Faculdade de Ciências Médicas e da Saúde de Juiz de Fora, Juiz de Fora, Minas Gerais, Brazil.

Chief Editor: Rosiane Viana Zuza Diniz

Associate Editor: Izabel Cristina Meister Martins Coelho

Received on 09/25/20; Accepted on 02/24/21.

Evaluated by double blind review process. 


\section{INTRODUCTION}

Mental health was included as one of the top ten health indicators ${ }^{1}$ and in the national objectives published in Health People 2010 (USA Department of Health and Human Services, 2000). Aspects of well-being deserve attention, both theoretically and clinically, mainly because they are associated with a wide range of diseases ${ }^{2}$, including depression and anxiety - common and debilitating mental disorders. Studies have shown a significant association between mental health, religiosity and spirituality $(R / S)^{3}$, mainly with the emergence of the "evidence-based spirituality"4 concept.

According to Koenig et al. ${ }^{5}$ religiosity is how much the individual believes in a religion, practices it with an organized system of beliefs and is part of a defined community, while spirituality is the personal search on existential issues, such as the meaning of life, and its associations with the transcendent reality, including or not a formal religious performance.

Scientific articles have shown that spiritual interventions increase optimism and reduce pessimism, especially in cases of illness ${ }^{6}$; and that R/S interventions promote greater acceptance and social support, with a deeper understanding of one's existence ${ }^{7}$. In adolescence, religion plays an important role in the socialization process and personality formation, being a protective factor against drug use, cigarette smoking and early onset of sexual activity, but its effect on health is less known ${ }^{8}$. That is because most of the articles that associated religious variables to positive health results did not include young individuals, but the elderly and the ill9. Despite this context of few studies, it is known that university students face many conflicts (educational, cultural and financial) ${ }^{10}$ and that medical students suffer more stress when compared to those attending other courses. Moreover, depression rates increase over the course of medical training, with a significant association with diseases and a decrease in academic performance ${ }^{9}$.

Although there are studies correlating $\mathrm{R} / \mathrm{S}$ and depression, anxiety is largely ignored ${ }^{8}$. Another aspect related to the articles is the difficulty using the concepts of religiosity and spirituality, often seen as synonyms ${ }^{11}$. The diversity of protocols and results associated with the lack of study standardization indicates the need for further studies evaluating spirituality in health ${ }^{7}$.

Throughout life, the individual is exposed to situations that can negatively affect their well-being and, in the context of mental health, it is suspected that religiosity contributes as a protective factor. The aim of the present study is to assess whether the degree of $\mathrm{R} / \mathrm{S}$ of medical students attending a health institution in the city of Juiz de Fora, state of Minas Gerais, Brazil, influences anxiety and depression disorders during undergraduate school.

\section{METHODS}

This study was carried out with a non-probabilistic, convenience sample, consisting of 298 undergraduate medical students, from a private Higher Education Institution located in Juiz de Fora, state of Minas Gerais, Brazil, from April to June 2019. Students were attending the first, second, sixth, seventh, eleventh and twelfth semesters of undergraduate school at the time of the study (2019); the choice of undergraduate periods was made so that it was possible to make comparative analyses of students at the beginning, in the middle and at the end of the medical course.

The study was approved by the Research Ethics Committee of the institution, under CAAE number 04329318.6.0000.5103 and the students voluntarily agreed to participate by signing the Free and Informed Consent form.

Data related to 15 individuals who did not meet the study inclusion criteria were excluded, as they were not within the age range of 18 to 30 years. Additionally, another 16 individuals did not correctly complete the key variables of this study and were also excluded from the analysis. It was also observed that two individuals did not include their respective age and thus, these were filled out with the mean age of the students attending the same semester in which they were enrolled. In all, 267 individuals were part of the statistical analysis.

The questionnaires were applied to students during the school period, before or after classes, in the classroom. The researchers informed about the study objectives before handing out the questionnaires, and these were filled out by the students themselves.

As an assessment tool, the Duke University Religiosity Index in Brazilian Portuguese (P-DUREL) was used, whereas the DASS-21 was applied in the form of a questionnaire to map depression, anxiety and stress. Additionally, a sociodemographic questionnaire (gender, age, ethnicity, religion and semester of undergraduate school) was applied to assess the contribution of such data to the result.

P-DUREL is a concise and easy-to-apply instrument, which allows obtaining the multidimensional measure of religiosity, consisting of five items that assess the three main dimensions of religious involvement related to health outcomes: Organizational Religious Activity (ORA) - religious meetings; Non-Organizational Religious Activity (NORA) private religious activities (such as prayer, meditation and reading); and Intrinsic Religiosity (IR) - seeking to internalize and experience religiosity ${ }^{12,13}$.

DASS-21 is a set of three Likert-type, four-point subscales of auto-response (0 to 3 ). Each subscale consists of seven items, which assess the emotional states of depression, anxiety and stress. It is worth mentioning that the depression 
subscale evaluates symptoms, such as inertia; anhedonia; dysphoria; lack of interest; self-depreciation; devaluation of life and hopelessness. While the anxiety subscale assesses the autonomic nervous system excitation; musculoskeletal effects; situational anxiety; and subjective anxiety experiences. And finally, the stress subscale assesses difficulty in relaxing; nervous excitation; easy disturbance/agitation; irritability/overreaction and impatience ${ }^{14,15}$.

The statistical analysis of the data was carried out using the Statistical Package for the Social Sciences (SPSS) software, version 20 for Windows. After the data transcription into the software, an exploratory analysis was performed to recognize the variables and correct any errors and/or inconsistencies in data collection and typing.

To achieve the aim of this study, the data analysis consisted of their description through means, standard deviation, calculation of the internal consistency (Cronbach's alpha) ${ }^{16}$ of the DUREL and DASS-21 instruments, Analysis of Variance (ANOVA), Welch's test ${ }^{17-19}$ and Chi-square test of independence ${ }^{20}$. The confidence interval comprised a $95 \%$ confidence and the $p$-value was equal to 0.05 in all performed statistical tests.

\section{RESULTS}

The analyzed group consisted of 267 medical students. The mean age was 22.16 ( \pm 2.90 ) years, with a minimum of 18 and a maximum of 30 years. Of the total, 184 were females, representing approximately $68.91 \%$ of the sample and 83 were males, approximately $31.09 \%$ of the sample. Regarding the selfdeclared ethnicity, $90.26 \%$ were white, $1.5 \%$ black, $0.37 \%$ chose not to declare ethnicity and the remainder belonged to other ethnicities. Table 1 also shows the students' religious affiliation.

As for the descriptive statistics of absolute (n) and relative (\%) frequency of the DUREL instrument, the following results were obtained (Table 2 ).

Table 1. Undergraduate students' religious affiliation.

\begin{tabular}{lcc}
\hline \multicolumn{1}{c}{ Religious affiliation } & \multicolumn{2}{c}{ Frequencies } \\
& N & $\%$ \\
\hline Catholic & 123 & 46.07 \\
Protestant & 23 & 9.74 \\
Spiritualist & 33 & 12.36 \\
Other & 3 & 1.12 \\
Does not believe in God & 21 & 7.87 \\
Believes in God, but has no religion & 48 & 17.98 \\
Believes in forces & 1 & 0.37 \\
Adventist & 1 & 0.37 \\
Buddhist & 1 & 0.37 \\
Catholic and Spiritualist & 4 & 1.50 \\
Catholic, Spiritualist and Umbandista & 1 & 0.37 \\
Umbandista & 1 & 0.37 \\
Agnostic & 4 & 1.50 \\
\hline
\end{tabular}

Table 2. Descriptive statistics for the DUREL instrument.

\section{Undergraduate student's profile regarding organizational religious activity (ORA)}

\begin{tabular}{lccccccc}
\hline & & $\begin{array}{c}\text { More than } \\
\text { once/week }\end{array}$ & $\begin{array}{c}\text { Once/ } \\
\text { week }\end{array}$ & $\begin{array}{c}\text { Two to } \\
\text { three times/ } \\
\text { month }\end{array}$ & $\begin{array}{c}\text { A few times } \\
\text { a year }\end{array}$ & $\begin{array}{c}\text { Once / year } \\
\text { or less }\end{array}$ & $\begin{array}{c}\text { Never } \\
\text { church, temple or other religious meeting }\end{array}$ \\
\cline { 2 - 8 } & $\mathrm{n}$ & 14 & 40 & 28 & 88 & 49 \\
& $\%$ & 5.24 & 14.98 & 10.49 & 32.96 & 18.35 & 17.98 \\
\hline
\end{tabular}

Undergraduate student's profile regarding non-organizational religious activity (NORA)

Frequency with which one dedicates to individual religious activities (prayers, meditations, reading religious texts)

\begin{tabular}{ccccccc} 
& $\begin{array}{c}\text { More than } \\
\text { once a day }\end{array}$ & Daily & $\begin{array}{c}\text { Two or } \\
\text { more times/ } \\
\text { week }\end{array}$ & Once/week & $\begin{array}{c}\text { Few times/ } \\
\text { month }\end{array}$ & $\begin{array}{c}\text { Rarelyor } \\
\text { never }\end{array}$ \\
\hline $\mathrm{n}$ & 17 & 90 & 40 & 16 & 39 & 65 \\
$\%$ & 6.36 & 33.71 & 14.8 & 5.99 & 14.61 & 24.34 \\
\hline
\end{tabular}

Undergraduate student's profile regarding intrinsic religiosity (IR)

\begin{tabular}{lccccccc}
\hline & \multicolumn{2}{c}{$\begin{array}{c}\text { Totally true } \\
\text { for me }\end{array}$} & $\begin{array}{c}\text { In general, } \\
\text { it is true }\end{array}$ & $\begin{array}{c}\text { I am not } \\
\text { sure }\end{array}$ & $\begin{array}{c}\text { In general, it } \\
\text { is not true }\end{array}$ & Is not true \\
\cline { 2 - 7 } $\begin{array}{l}\text { In my life, I feel the presence of God or the } \\
\text { Holy Spirit. }\end{array}$ & $\mathrm{n}$ & 128 & 67 & 27 & 21 & 24 \\
My religious beliefs are really enmeshed & $\mathrm{n}$ & 60 & 95 & 38 & 7.87 & 8.99 \\
into my entire way of living. & $\%$ & 22.47 & 35.58 & 14.23 & 11.24 & 16.48 \\
I work hard to experience religion in all & $\mathrm{n}$ & 37 & 90 & 48 & 33 & 59 \\
aspects of my life. & $\%$ & 13.96 & 33.71 & 17.97 & 12.36 & 22.1 \\
\hline
\end{tabular}


After this first step, the internal consistency of the instruments was evaluated. For this purpose, Cronbach's alpha coefficient was used, which is an inherent property of the response pattern of the studied population (STREINER, 2003), obtaining 0.90 of reliability measure for the DUREL instrument and 0.93 for the DASS-21 questionnaire, demonstrating that they offer accurate measurements and do not have redundant data.

To assess whether there is a difference in the rates of emotional disorders between students attending different semesters, the possible statistical significance was verified between the mean scores of these disorders, performing the analysis of variance (ANOVA), as well as the Welch's test.

The ANOVA of the students' anxiety score in their respective undergraduate semesters found no significance ( $p$-value $=0.45)$, that is, the undergraduate semester attended by the students does not influence their anxiety level. The collected data also makes it possible to analyze the level of anxiety of students in their respective semesters, as shown in the Chart below.

Regarding the Depression Score, it was necessary to carry out a more robust test against violations of homogeneity demonstrated by the ANOVA ( $p$-value $=0.001)$ :Welch's test, which diagnoses whether the sample means are statistically equal or not. The achieved result using the statistical software showed that the mean depression score for the different undergraduate semesters was not statistically equal ( $p$-value $<0.05$ ); $p$-value (Welch's test) $=0.048$. To verify where this difference exists, we used the post-hoc LSD test, and it showed there is a significant difference between the mean depression score of students attending the second semester and students attending the sixth semester, since the $p$-value $<0.05$ ( $p$-value $=0.025$ ), with the higher mean depression score being that of students attending the second semester. There is also a statistically significant difference between the mean depression score of students attending the twelfth and sixth semesters, with $p$-value $<0.05$ ( $p$-value $=0.020$ ), with the higher mean depression score being that of students attending the twelfth semester. Finally, there was a statistically significant difference between the mean depression score of students attending the twelfth semester and those in the eleventh semester, with a $p$-value $<0.05$ ( $p$-value $=$ 0.042 ), being higher in students attending the twelfth semester. There was no difference between the other semesters.

Chart 1. Anxiety level and undergraduate semester.

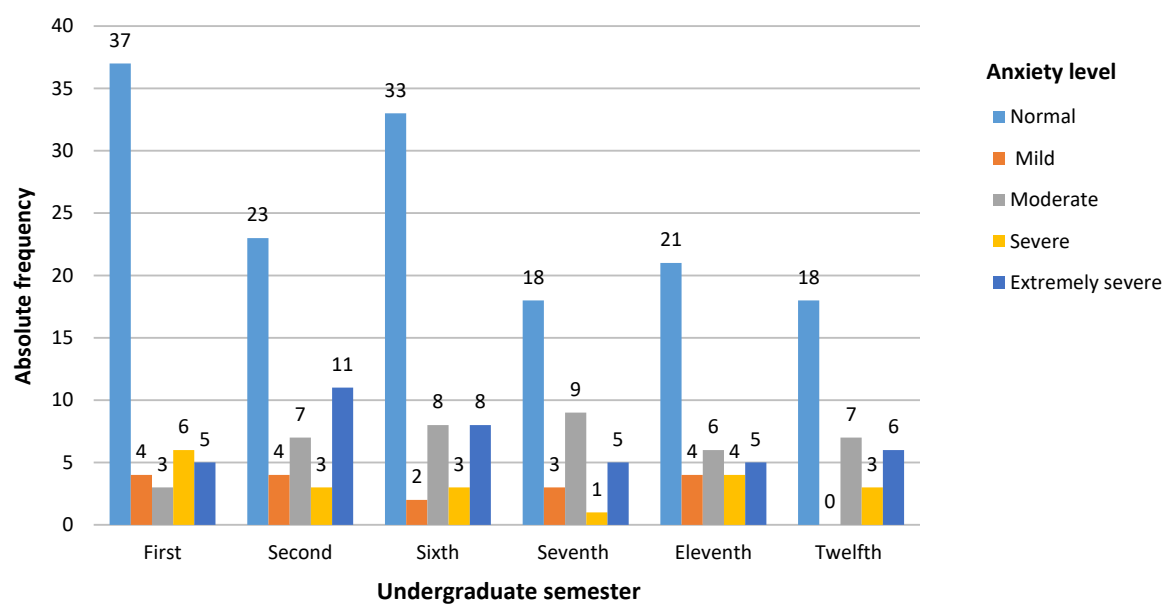

Chart 2. Level of depression and undergraduate course semester.

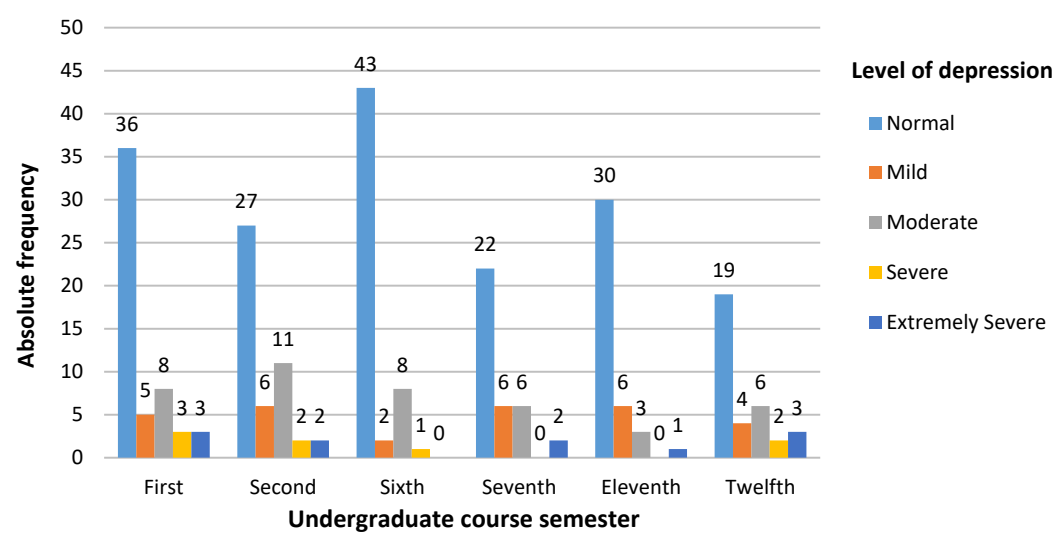


Chart 3. Level of stress and undergraduate semester.

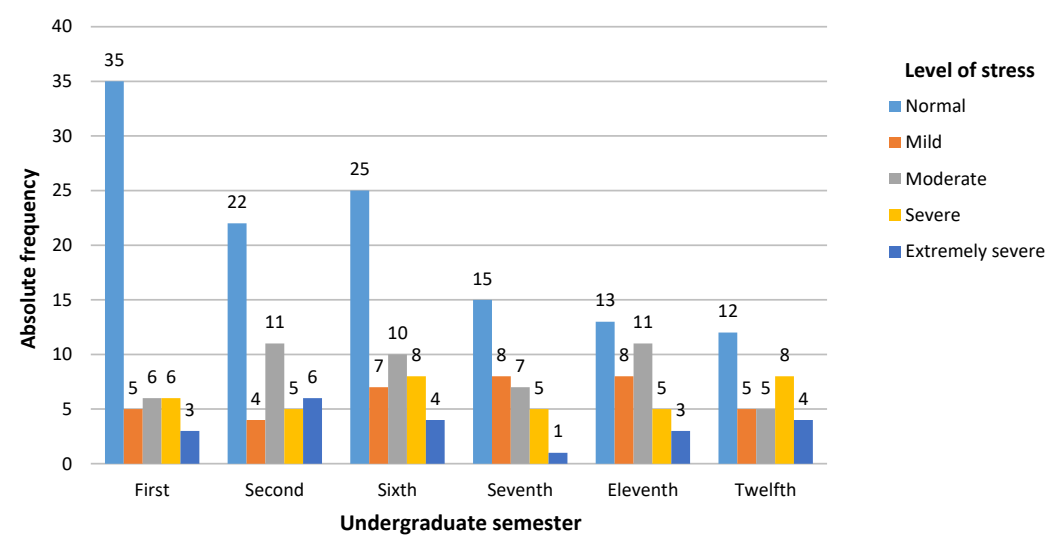

In view of the above, one can affirm that the undergraduate course semester influenced the students' level of depression. Moreover, the chart below analyzes the students' level of depression.

Regarding stress, the analysis of the $p$-value $>0.05$ ( $p$-value $=0.23$ ) of ANOVA showed there is no significant difference between the mean stress scores of individuals attending the different undergraduate semesters. The chart below shows the students' level of stress in their respective undergraduate semesters (Chart 3).

Regarding the prevalence of the assessed mental disorders, it was observed that most students have normal levels of anxiety, depression and stress, with a relative frequency of $56.18 \%, 66.29 \%$ and $45.69 \%$, respectively. It is worth noting that a considerable number of the students have higher intensity disorders, with $22.47 \%$ of anxious, $21.73 \%$ stressed and $7.21 \%$ depressed students showing severe and extremely severe levels.

Finally, we evaluated the association between the religious aspects and the emotional disorders. As seen in table 2, two of the three dimensions of the DUREL Religiosity Index, ORA and NORA, consist each of a question that contains six alternatives, which specify the level of association of the student with that respective dimension. Aiming to allow associations between this instrument and the emotional disorder scale, DASS-21, the following conversions were made:

- Alternatives 1, 2 and 3 of the questions $\rightarrow$ "Positive Association" to religiosity;

- Alternatives 4, 5 and 6 of the questions $\rightarrow$ "Absence of Association".

Conversely, in the intrinsic religiosity (IR) dimension, consisting of three statements (IR 1, IR 2 and IR 3), each with five alternatives that specify the level of association with this dimension, the conversion was:
- Alternatives 1 and 2 of the assertions $\rightarrow$ "Positive Association";

- $\quad$ Alternatives 3,4 and 5 of the assertions $\rightarrow$ "Absence of Association".

- Similarly, the levels of emotional disorders (normal, mild, moderate, severe and extremely severe) were converted into:

- "Absence of signs" of the observed emotional disorder, previously called the "normal" level;

- "Presence of signs" of the observed emotional disorder, previously called "mild", "moderate", "severe" and "extremely severe" levels.

Through the Chi-square test ( $x 2)$ of independence, it was assessed whether the presence or absence of emotional disorders is related to the positive or negative association to religiosity aspects. The results showed that the ORA dimension has no association with the students' emotional disorders of depression ( $p$-value $=0.65$ ), anxiety ( $p$-value $=0.43$ ) and stress ( $p$-value $=0.23$, and that the degree of association between these variables, expressed through the Phi measure, was 3\%, $5 \%$ and $7 \%$, respectively.

Regarding the NORA dimension, the results also showed that this dimension has no association with the students' emotional disorders of depression ( $p$-value $=0.69$ ), anxiety $(p$-value $=0.69)$ and stress $(p$-value $=0,77)$, and that the degree of association between these variables was $2 \%, 2 \%$ and $2 \%$, respectively.

Similarly, the IR dimension showed no association with the students' emotional disorders of depression ( $p$-value $=$ 0.83 ), anxiety ( $p$-value $=0.12$ ) and stress ( $p$-value $=0.09$ ), and the degree of association between these variables was $1 \%$, $9 \%$ and $10 \%$, respectively. Regarding IR 2, there was also no significant association [depression ( $p$-value $=0.83$ ), anxiety $(p$-value $=0.20)$ and stress $(p$-value $=0.23)$ and the degree 
of association between these variables was $12 \%, 8 \%$ and $7 \%$, respectively]. Finally, the results of item IR 3 were: $p$-value $=0.21$ for signs of depression; ( $p$-value $=0.93$ ) for signs of anxiety; and ( $p$-value $=0.63$ ) for signs of stress, and the degree of association between these variables was $8 \%, 1 \%$ and $3 \%$, respectively.

\section{DISCUSSION}

Data presented by the last IBGE census showed that the Brazilian population is mostly Christian, with Catholic affiliation, but there is an increase in the number of people not affiliated with any religion ${ }^{21}$, which is well represented in the sample of the present study.

Even though religious values are still widely used by young individuals with a high level of education, a population that is exposed daily to situations that affect their mental health ${ }^{20}$, it was demonstrated that all dimensions of ORA, NORA and IR do not have a statistically significant association with the students' emotional disorders of depression, anxiety and stress. This can be based on the fact that the $\mathrm{R} / \mathrm{S}$ have a qualitative feature, difficult to be measured ${ }^{10}$ with universal instruments, even if they have been validated, being necessary to investigate the sample individualities.

When compared with previously published scientific articles about depression, the present study corroborates the one by Luiz Gonçalves JR et al. ${ }^{22}$, whose result showed that none of the R/S variables was associated with depression in a sample of students from the health are (Medicine and Nursing). Moreover, this same study concluded that ORA was a protective factor against anxiety, but this divergence can be justified by methodological differences in the study, since they used a selfspirituality scale and the hospital scale of anxiety and depression.

A similar study with students from Israel $^{23}$ also showed no association between R/S, depression and anxiety, showing that the results can be similar even in different cultures.

Gonçalves JP et al. ${ }^{6}$, in a meta-analysis, showed that despite the positive correlations, there are also associations between $\mathrm{R} / \mathrm{S}$ and pessimistic thoughts of guilt or punishment, for instance: committing a sin, which culminates in negative results - higher prevalence of depression and anxiety. The power of belief in these thoughts of loss can be influenced, among other variables, by the index of religiosity and, thus, be connected to a higher rate of depression?.

Our results also reinforce the theses ${ }^{24,25}$ that the challenges at the beginning and end of medical school ${ }^{14}$ experiencing the unknown and responsibilities - exacerbate the students' anxiety. Therefore, the prevalence of mental disorders in medical students is high, especially in the extremities of undergraduate school (second and twelfth semesters).

On the other hand, Bassols et al., in a Brazilian study, found a higher prevalence of anxiety symptoms in first-year medical students when compared to students at the end of undergraduate school ${ }^{26}$, which differs from the results obtained in the present study, since only depression symptoms attained significantly different mean scores between the semesters.

Regarding the limitations, the non-association between $\mathrm{R} / \mathrm{S}$ and mental health found in the present study reinforces the need for longitudinal research to investigate the most prevalent multidimensional aspects in different religions.

As this is a cross-sectional study, the moment when the questionnaires are applied may constitute a bias, since the stressors are not homogeneous throughout the semester, such as the return to classes after holidays and the period close to evaluations. As the study was carried out with students from a single institution, generalization requires caution, since the academic requirements and psychosocial support might interfere with the results ${ }^{22}$. Another aspect related to the articles is the difficulty in defining complex and multifaceted concepts, such as religiosity and spirituality, as there is no universal definition for those?

On the other hand, the present study also has considerable strengths. The questionnaires used in the study have been validated in the volunteers' language, are easy to apply and understand, and have worldwide reproducibility ${ }^{14}$.

\section{CONCLUSION}

Considering the above, the study allows us to propose recommendations for future research so that the results can be used in meta-analysis studies, investigating the more prevalent multidimensional aspects in different religions, while keeping in mind that it is still necessary to carry out more longitudinal studies. Finally, it is important to observe that studies like the present one, which did not show a significant association between the variables, cannot be neglected, so that the positive and negative dimensions of the association between $R / S$ and mental health can be investigated.

\section{AUTHORS' CONTRIBUTION}

Larissa Cruvinel Leite and Larissa Vitoria Dornelas created the project, collected the data, discussed the findings and wrote the manuscript. Laura de Souza Bechara Secchin was the project advisor regarding the work performance and contributed to the manuscript review.

\section{CONFLICTS OF INTEREST}

The authors declare no conflicts of interest in this study.

\section{SOURCES OF FUNDING}

The authors declare there were no external sources of funding for this research. 


\section{REFERENCES}

1. Wong YJ, Rew L, Slaikeu KD. A systematic review of recent research on adolescent religiosity/spirituality and mental health. Issues Ment Health Nurs. 2006;27(2):161-83.

2. Kioulos KT, Bergiannaki JD, Glaros A, Vassiliadou M, Alexandri Z, Papadimitriou G. Religiosity dimensions and subjective health status in Greek students. Psychiatriki. 2015;26(1):38-44.

3. Carlotto RC. Spirituality and depressive symptoms in Brazilian college students. Rev Psicol UNESP. 2013;12(2):50-60.

4. Zanetti GC, Lemos GL, Gotti ES, Tomé JM, Silva AP, de Rezende EAMR. The perception of medical students as well as students from other healthrelated areas regarding the relations between spirituality, religiosity and health. Rev Bras Educ Med. 2018;42(1):65-72.

5. Koenig HG, McCullough M, Larson DB. Handbook of religion and health: a century of research reviewed. 2nd ed. New York: Oxford University Press; 2001.

6. Gonçalves JPB, Lucchetti G, Menezes PR, Vallada H. Religious and spiritual interventions in mental health care: a systematic review and meta-analysis of randomized controlled clinical trials. Psychol Med. 2015;45(14):2937-49.

7. Koenig HG, Pearce MJ, Nelson B, Daher N. Effects of religious versus standard cognitive-behavioral therapy on optimism in persons with major depression and chronic medical illness. Depress Anxiety. 2015;32(11):835-42.

8. Pikó B, Kovács E. Is religiosity a protective factor? Social epidemiologic study of adolescent psychological health. Orv Hetil. 2009;150(41):1903-8.

9. Vasegh S, Mohammadi MR. Religiosity, anxiety, and depression among a sample of Iranian medical students. Int J Psychiatry Med. 2007;37(2):213-27.

10. Chaves EC, lunes HD, Moura CC, Carvalho CL, Silva AM, Carvalho EC. Anxiety and spirituality in university students: a cross-sectional study. Rev Bras Enferm. 2015;68(3):504-9.

11. Chaves, F. Religião, religiosidade ou espiritualidade? A importância da definição dos termos no contexto de saúde física e psíquica. POHSA. 2015;5(14).

12. Taunay TCE, Gondim FAA, Macêdo DS, Moreira-Almeida A, Gurgel LA, Andrade LMS, et al. Validity of the Brazilian version of the Duke Religious Index (DUREL). Rev Psiquiatr Clín. 2012;39(4):130-5.

13. Koenig HG, Büssing A. The Duke University Religion Index (DUREL): a five-item measure for use in epidemiological studies. Religions. 2010;1(1):78-85.

14. Moutinho IL, Maddalena NC, Ronald RK, Lucchetti ALG, Tibiriça SHC, Ezequiel OS, et al. Depression, stress and anxiety in medical students: a cross-sectional comparison between students from different semesters. Rev Assoc Med Bras. 2017;63(1):21-8.
15. Apóstolo JLA, Mendes AC, Azeredo ZA. Adaptation to Portuguese of the Depression, Anxiety and Stress Scales (DASS). Rev Lat Am Enfermagem. 2006;14(6):863-71.

16. Almeida D, Santos MAR, Costa AFB. Aplicação do coeficiente alfa de Cronbach nos resultados de um questionário para avaliação de desempenho da saúde pública. Anais do XXX Encontro Nacional de Engenharia de Produção. Maturidade e desafios da engenharia de produção: competitividade das empresas, condições de trabalho, meio ambiente; 12-15 out. 2010; São Carlos, SP, Brasil. São Carlos: Abepro; 2010.

17. Blanca MJ, Alarcón R, Arnau J. Non-normal Data: is ANOVA still a valid option? Pshicothema. 2017;29(4):552-7.

18. Montgomery DC. Design and analysis of experiments. 9th ed. Hoboken, NJ: John Wiley \& Sons; 2017.

19. Scheffé $H$. The analysis of variance. New York: John Wiley \& Sons; 1999.

20. Campbell I. Chi-squared and Fisher-Irwin tests of two-by-two tables with small sample recommendations. Stat Med. 2007;26(19):3661-75.

21. Instituto Brasileiro de Geografia e Estatística. Censo Demográfico 2010. Características gerais da população, religião e pessoas com deficiência. Rio de Janeiro: IBGE; 2010 [access in 24 jul 2020]. Available from: http:// biblioteca.ibge.gov.br/visualizacao/periodicos/94/cd_2010_religiao_ deficiencia.pdf.

22. Gonçalves JRL, Jorge AP, Zanetti GC, Amaro EA, Tótoli RT, Lucchetti G. Religiousness is associated with lower levels of anxiety, but not depression, in medical and nursing students. Rev Assoc Med Bras. 2018;64(6):537-42.

23. Lupo MK, Strous RD. Religiosidade, ansiedade e depressão entre estudantes de medicina israelenses. Isr Med Assoc J. 2011;13(10):613-8.

24. Miller $P$, Surtees $P$. Sintomas psicológicos e seu curso em estudantes de medicina do primeiro ano, avaliados pelo Interval General Health Questionnaire (I-GHQ). Ir J Psiquiatria. 1991;159(2):199-207.

25. Quince TA, Wood DF, Parker RA, Benson J. Prevalence and persistence of depression among undergraduate medical studentes: a longitudinal study at one UK medical school. BMJ Open. 2012;2(4):e001519.

26. Bassols AM, Okabayashi LS, Silva AB, Carneiro BB, Feijó F, Guimarães GC, et al. First- and last-year medical students: is there a difference in the prevalence and intensity of anxiety and depressive symptoms. Rev Bras Psiquiatr. 2014;36(3):233-40. 